\title{
АКТИВИЗАЦИЯ АВАЧИНСКОГО ВУЛКАНА В 2019 г.
}

\author{
(C) 2021 г. П. П. Фирстов ${ }^{a, *}$, А. А. Шакирова ${ }^{a, ~ * *}$, А. П. Максимов ${ }^{b}$, Е. В. Черных ${ }^{b}$ \\ ${ }^{a}$ Камчатский филиал Федерального исследовательского иентра “Единая геофизическая служба РАН”, \\ бульвар Пийпа, 9, Петропавловск-Камчатский, 683006 Россия \\ ${ }^{b}$ Институт вулканологии и сейсмологии ДВО РАН, бульвар Пийпа, 9, Петропавловск-Камчатский, 683006 Россия \\ *e-mail:firstov@emsd.ru \\ **e-mail: shaki@emsd.ru \\ Поступила в редакцию 03.08.2020 г. \\ После доработки 20.10.2020 г. \\ Принята к публикации 11.12.2020 г.
}

\begin{abstract}
На основании изучения волновых форм и спектрального состава землетрясений, зарегистрированных в период активизации Авачинского вулкана в 2019 г., были выделены три общепринятых типа вулканических землетрясений (В3): вулкано-тектонические, гибридные и длиннопериодные, а также четвертый - “особый” тип В3, отличающийся особенностями волновых форм. Выделены 15 плоско-ориентированных кластеров и определены характеристики сейсмогенных площадок. Анализ сейсмических событий, зафиксированных осенью 2019 г. в Молодом конусе Авачинского вулкана, позволил предположить связь активизации с магматическими телами извержения 1991 г. в теле конуса и их взаимодействием с атмосферными осадками. Наиболее вероятной причиной световых вспышек над кратером, наблюдавшихся 8 декабря, представляется взаимодействие обогащенного водородом вулканического газа при контакте с кислородом воздуха.
\end{abstract}

Ключевые слова: активизация, сейсмичность, плоско-ориентированные кластеры, гидротермальная активность

DOI: $10.31857 / \mathrm{S} 0203030621030032$

\section{ВВЕДЕНИЕ}

Извержения Авачинского вулкана ${ }^{1}$, расположенного вблизи краевого центра г. Петропавловск-Камчатский (23 км) и международного аэропорта Елизово (30 км), представляют потенциальную опасность для агломерации с населением более 200 тыс. (рис. 1а). В связи с этим сейсмическая активизация осенью 2019 г. вызвала особенный интерес у научной общественности [Малик, Некрасова, 2020; Муравьев, 2020; Шакирова и др., 2020].

Морфологически вулкан относится к типу Сомма-Везувий: голоценовый вулкан Молодой конус располагается в кратере позднеплейстоценового вулкана Палео-Авача, с которым связана вся современная активность. За период с 1737 г. по настоящее время известно 15 извержений, которые значительно различаются по характеру и интенсивности [Мелекесцев и др., 1994, 2002].

После наиболее сильного эксплозивного извержения субплинианского типа в 1945 г., на вулкане образовался кратер диаметром $\sim 250$ м и глубиной $\sim 170$ м. Следующее извержение в январе

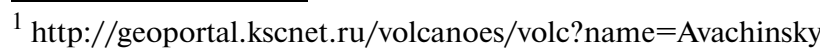

1991 г. носило, преимущественно, эффузивный характер. В результате этого извержения в кратере образовалась мощная лавовая пробка объемом $8.3 \times 10^{6} \mathrm{M}^{3}$, и на склоны вулкана излился лавовый поток $\left(\mathrm{V}=4.4 \times 10^{6} \mathrm{M}^{3}\right)$ [Мелекесцев и др., 1994; Иванов и др., 1995]. В результате следующего извержения 5 октября 2001 г., в виде слабой газовой эксплозии высотой $\sim 1000$ м над кратером с выбросом небольшого количества пепла и обломков пород извержения 1991 г., образовалась трещинаров, рассекшая лавовую “пробку” в С3-ЮВ направлении с азимутом $325^{\circ}$ [Мелекесцев и др., 2002].

Тепловая съемка, выполненная 6 ноября 2001 г., показала термические аномалии в центре трещины и по ее краям, причем проекция центра трещины совпадала с тепловой аномалией в донной части кратера, где началось излияние лавы в 1991 г. [Дубровская и др., 2019]. На снимках трещины просматриваются контуры воронок, которые, повидимому, образовались в результате эксплозии (см. рис. 1б, врезка). Следует отметить, что в обоих случаях перед извержениями регистрировались вулканические землетрясения (В3) с энергетическим классом $K<6.6$ ( $K=\lg E$, Дж), в основном, происходящие в постройке вулкана [Сенюков и др., 
(a)

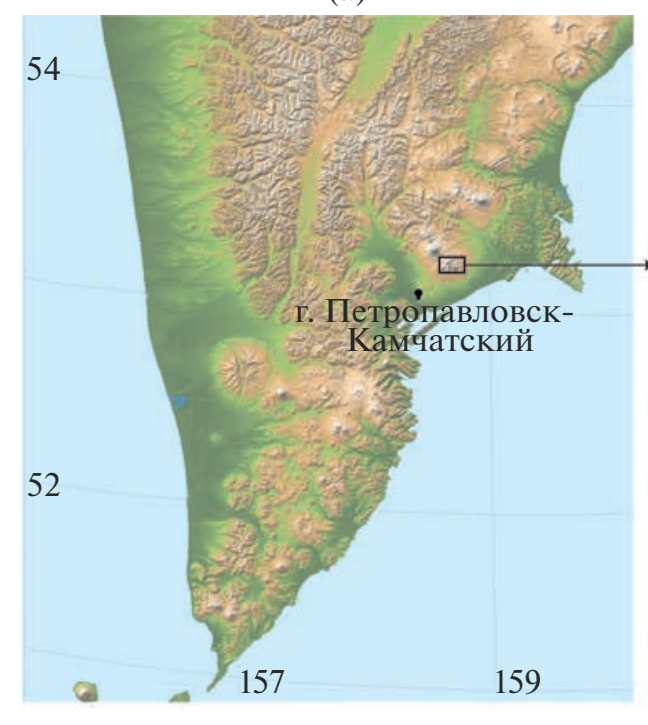

(б)

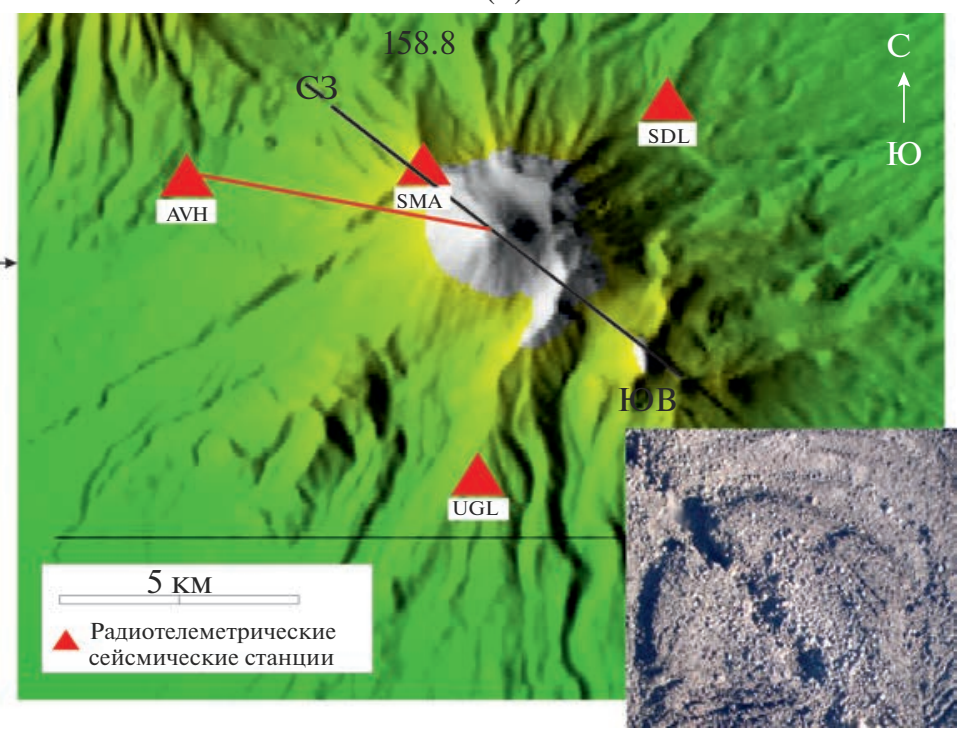

Рис. 1. Расположение вулкана Авачинский (а) и РТСС в его окрестности (б).

На врезке: образовавшаяся на пробке трещина после извержения 2001 г. Красной линией показано направление обзора видеокамеры РTCC AVH. Название PTCC: AVH - Авача, SMA - Coмма, SDL - Cедловина, UDL - Угловая. Съемка 28.06.2005 г. Фото И.К. Дубровской.

2006]. Однако, сравнительно слабая сейсмическая активность в первом случае и отсутствие опыта прогноза извержений для этого вулкана во втором случае не позволили дать краткосрочный прогноз обоих извержений.

Для Авачинского вулкана характерна постоянная фумарольная активность с целой сетью отдельных фумарол, расположенных по периферии кратера и на окончаниях трещины-рва. Температуры фумарол колеблются в широких пределах, наиболее мощные достигают температур свыше 600-800 С [Малик и др., 2017].

В октябре-декабре 2019 г. наблюдалось усиление сейсмической активности Авачинского вулкана. С 27 октября на инфракрасной камере Камчатского филиала Федерального исследовательского центра "Единая геофизическая служба РАН” (КФ ФИЦ ЕГС РАН), установленной на радиотелеметрической сейсмической станции (РTCC) “Авача" (AVH) в 6 км от кратера вулкана (см. рис. 1б), было зафиксировано свечение в западной части кратера (http://www.emsd.ru/ ssl/ monitoring/main.htm). Визуально в этот период отмечалась повышенная фумарольная активность и сильная загазованность кратера.

В данной работе авторы дают подробное описание активности вулкана Авачинский в конце 2019 г. с упором на сейсмичность, и рассматривается разумное объяснение возможных механизмов ее возникновения.

\section{КРАТКИЕ СВЕДЕНИЯ О ВУЛКАНИЧЕСКИХ ЗЕМЛЕТРЯСЕНИЯХ}

Начиная с 1950-ых годов прошлого века, в процессе возникновения и развития научного направления “вулканическая сейсмология” стояла проблема классификации землетрясений, связанных с активностью вулканов, т.е. предшествовавших и сопровождавших извержения. Одной из первых попыток классификации В3 по форме записи и их связи с вулканической деятельностью была предпринята Г.С. Горшковым [1954а]. Так как в это время регистрация землетрясений была аналоговой с небольшим увеличением и малой скоростью развертки, то предложенная классификация была достаточно упрощенной. В следующей его работе [Горшков, 1954б] были затронуты вопросы терминологии и впервые дано определение "вулкано-тектонических", как землетрясений, имеющих волновую форму тектонических, но приуроченных к районам действующих вулканов.

В основу известной классификации японского исследователя [Minakami, 1961] положена связь В3 с активностью вулкана и местоположением их очагов. Позднее, на примере извержений вулканов Камчатки, П.И. Токаревым [1966] были выделены 5 типов В3, хорошо согласующихся с классификацией [Minakami, 1961]. Данная классификация используется российскими вулканологами и в настоящее время.

В дальнейшем, с применением в сейсмологии цифровой регистрации и компьютерной обработ- 
ки землетрясений, появилась возможность более детального исследования волновых форм В3 и большей точности определения координат очагов слабых В3, что послужило толчком к возникновению новой типизации В3, основы которой были заложены в работах [McNutt, 1996; Power et al., 1994; Гордеев, Сенюков, 1998; Zobin, 2017]. Выделяются три основных типа В3: вулкано-тектонические, гибридные и длиннопериодные, которые будут рассмотрены на примере землетрясений, зарегистрированных во время активизации Авачинского вулкана в 2019 г.

Кроме этих типов В3, наблюдаемых на всех вулканах мира, в некоторых случаях регистрировался еще один тип - "tornillo" ("винт", Т3), который характеризуется монохромным частотным спектром и большой длительностью кода-волн [Cannata et al., 2012; Gomez, 1999]. Так при сейсмических активизациях вулкана Вулькано 2 (Липарские острова, Италия), напоминающих активизацию Авачинского, регистрировались Т3, возникновение которых объяснялось взаимодействием водного флюида с магматическим телом [Milluzzo et al., 2010]. Также Т3 наблюдались на вулкане Галерас (Центральные Анды) перед и после извержений [Gomez, 1999].

Во время сейсмической активизации вулкана Иво-Дзима (Японские острова) в сентябре 1997 г. регистрировались Т3 и В3 с особой волновой формой. Особенностью В3 данного типа была предваряющая основной толчок короткая запись слабых колебаний (emergent phase). Предполагается, что такие землетрясения могут возбуждаться пузырьками газа с последующим сдвиговым разрушением высоковязкой риолитовой магмы [Uchida, Sakai, 2002].

\section{МЕТОДИКИ НАБЛЮДЕНИЙ И ОБРАБОТКА ИХ РЕЗУЛЬТАТОВ}

За активностью вулкана Авачинский ведется непрерывное видеонаблюдение с помощью цифровой IP-камеры, установленной на PTCC AVH, расположенной в 6 км от кратера (см. рис. 1б). Видеокамера позволяет вести съемку в видимом и инфракрасном диапазонах, что дает возможность осуществлять мониторинг динамики фумарольной активности (интенсивность и температура) над кратером вулкана. Во время активизации вулкана в конце 2019 г. камерой были зарегистрированы весьма интересные события. Данные мониторинга активности вулкана взяты с сайта КФ ФИЦ ЕГС РАН. (http://www.emsd.ru/ ssl/monitoring/main.htm)

Сейсмический режим района вулкана Авачинский контролируется сетью из четырех РТСС,

\footnotetext{
${ }^{2}$ Названия вулканов приведены согласно каталогу И.И. Гущенко [1979].
}

расположенных на расстояниях от 2.4 км до 6 км от кратера вулкана (см. рис. 1б). Данная сеть позволяет определять координаты слабых В3 в постройке вулкана с энергетическим классом $K_{S} \geq 1.5$ $\left(K_{S}=\log E\right.$, Дж).

Трехкомпонентный комплект короткопериодных каналов $(\mathrm{SH})$ на базе сейсмометра СM3 $\left(T_{S}=\right.$ $=1.2 \mathrm{c})$ позволяет регистрировать скорость смещения грунта в полосе частот 0.8-20 Гц. Для регистрации слабых землетрясений РТСС имеют высокочувствительный канал, регистрирующий вертикальную составляющую (EHZ), с резонансной характеристикой в диапазоне частот 8-12 Гц по уровню 0.7. Записи землетрясений привязаны к универсальному координированному времени (Coordinated Universal Time, UTC), которое также было использовано в статье.

Для вычисления координат очагов применялась локальная одномерная скоростная модель с возможностью поиска решений положений гипоцентров выше уровня моря [Сенюков, 2006]. Погрешность определения очагов землетрясений в районе вулкана Авачинский оценивается около одного километра как в плане, так и по глубине [Нуждина и др., 2019]. В работе анализировались параметры землетрясений, обработанных в режиме, близком к реальному времени, и опубликованных в служебной сетевой базе данных КФ ФИЦ ЕГС РАН (http://www.emsd.ru/ts/). Обработка землетрясений и вычисление их параметров осуществлялись с помощью интерактивной программы DIMAS [Дрознин, Дрознина, 2010; Droznin, Droznina, 2011]. В статье глубины гипоцентров выше уровня моря имеют знак “+”, а ниже “-”.

В работах [Кирюхин и др., 2016, 2017; Kiryukhin, 2017] разработана методика выделения в потоке В3 плоско-ориентированных кластеров на основании следующих критериев: 1) временное ограничение событий менее суток; 2) разброс гипоцентров землетрясений в горизонтальной плоскости $\leq 6$ км; 3) их удаление от плоскости сейсмогенной площадки $\leq 200$ м; 4) количество землетрясений в кластере $\geq 6$. В сейсмической активизации вулкана Авачинский в 2019 г. выделялись плоско-ориентированные кластеры и определялись характеристики сейсмогенных площадок в интерактивной программе FracDigger (№ 2016616880)³.

\footnotetext{
${ }^{3}$ Кирюхин П.А., Кирюхин А.В. Frac-Digger. Свидетельство о государственной регистрации программы для ЭВМ № 2016612168 от 21.06.2016.
} 


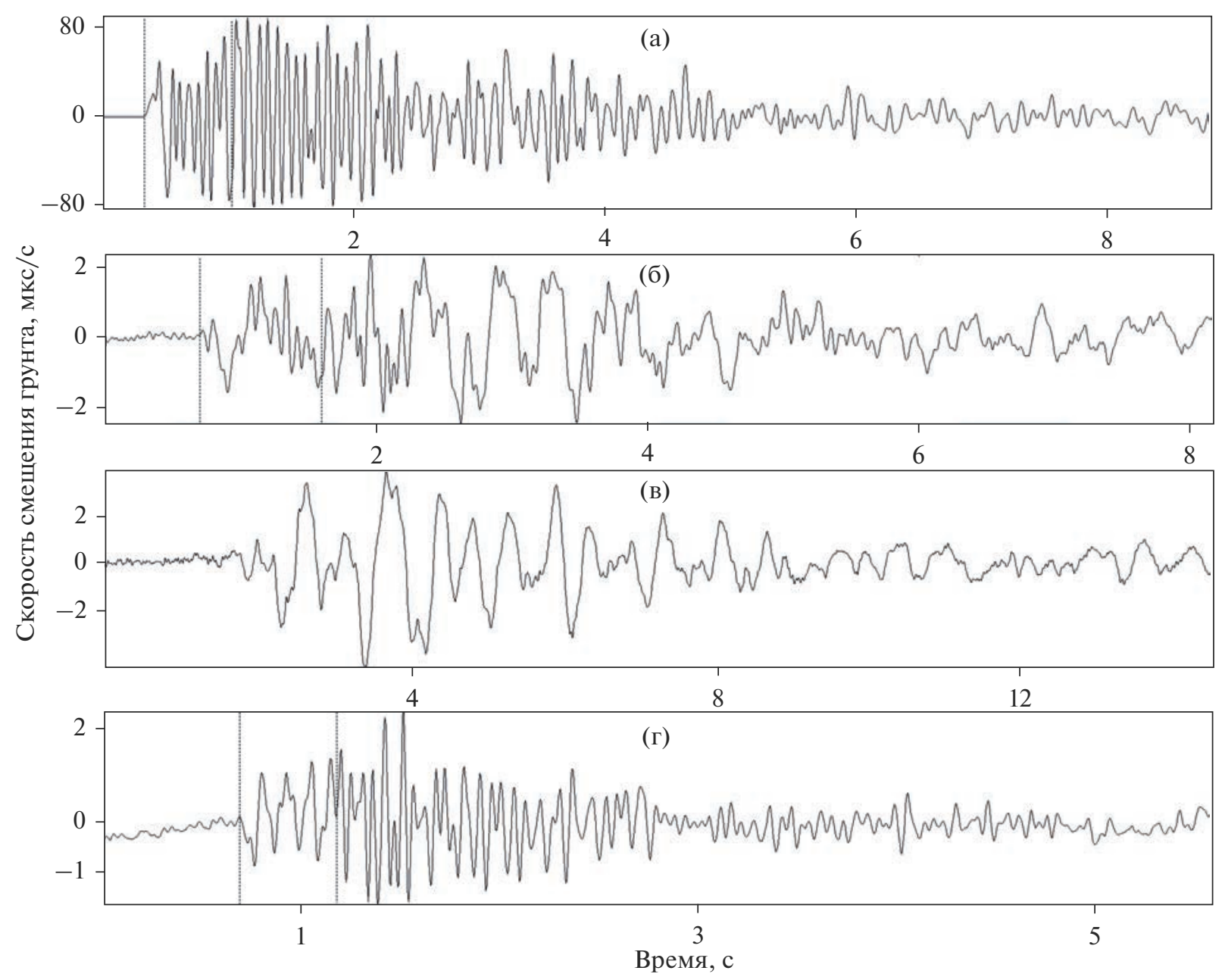

Рис. 2. Волновые формы землетрясений, зарегистрированных на вертикальной компоненте PTCC SMA (SHZ) во время активизации вулкана Авачинский в октябре-декабре 2019 г.

а - ВТ землетрясение 9.12.2019 г. в 14:54 с Ks $=6.6, \mathrm{H}=-1.42$ км; б - Г3 10.12.2012 г. в 23:03 с Ks $=3.5, \mathrm{H}=1.8 \mathrm{Kм;} \mathrm{в}-$ Д3 18.11.2019 г. в 09:09 с $K \mathrm{~s}=2.7, \mathrm{H}=1.8$ км; г - “особое” землетрясение 5.11.2019 г. в 11:46 с $\mathrm{Ks}=3.6, \mathrm{H}=1.8$ км.

\section{СЕЙМИЧЕСКИЕ ЯВЛЕНИЯ, ЗАРЕГИСТРИРОВАННЫЕ \\ В РАЙОНЕ ВУЛКАНА АВАЧИНСКИЙ В ОКТЯБРЕ-ДЕКАБРЕ 2019 Г.}

С конца октября 2019 г. в районе постройки вулкана Авачинский регистрировались В3 различных типов.

Выделение типов В3 в период активизации вулкана Авачинский в 2019 г. было осуществлено на основании волновых форм землетрясений и их спектрального состава, зарегистрированных на ближайшей к вулкану РTCC SMA. Были выделены три общепринятых типа и четвертый "особый” тип В3.

Вулкано-тектонические землетрясения (ВТЗ), обусловленные хрупким разрушением геосреды, имели четкие вступления $\mathrm{P}$ и $\mathrm{S}$-волн и $t_{\mathrm{s}-\mathrm{p}}=0.8 \mathrm{c}$ (рис. 2a). На спектрограммах ВТЗ выделяются интенсивные амплитудные плотности с частотами в диапазоне $f=12-15$ Гц (рис. 3a).

Гибридные землетрясения (ГЗ) характеризовались четкими вступлениями с $t_{\mathrm{s}-\mathrm{p}}=0.9 \mathrm{c}$, после которых наблюдалась запись явно выраженных кода-волн с более низкими частотами (см. рис. 2б). На спектрограмме ГЗ выделяются два пятна плотности с $f_{1}=6$ Гц в начальной части записи и с $f_{2} \approx$ $\approx 2$ Гц для коды-волн (см. рис. 3б). Механизм ГЗ принято связывать с процессом хрупкого разрушения геосреды с образованием трещины и дальнейшего ее заполнения магмой или флюидом [Гордеев, Сенюков, 1998].

Длиннопериодные землетрясения (Д3). Для них характерны нечеткие вступления Р- и S-волн и более низкая частота относительно предшествующих типов (см. рис. 2в). На спектрограмме в течение 5 с выделяется пятно спектральной плотности с $f \approx 1.5-2$ Гц (см. рис. 3в). Принято 
(a)
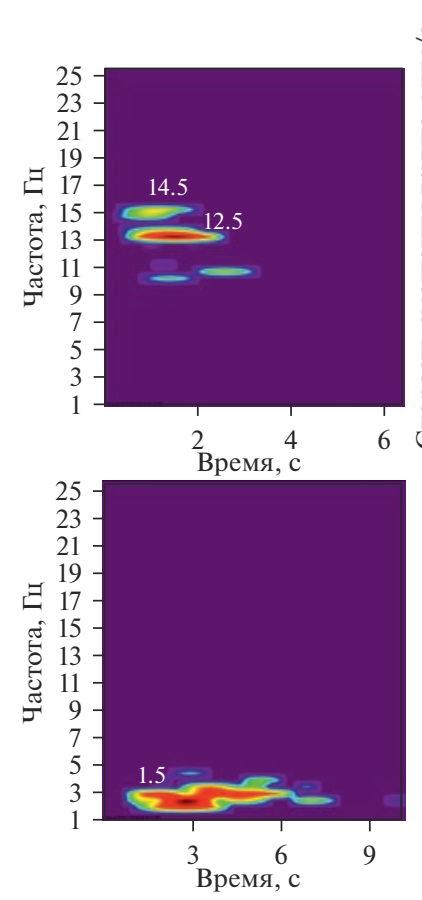
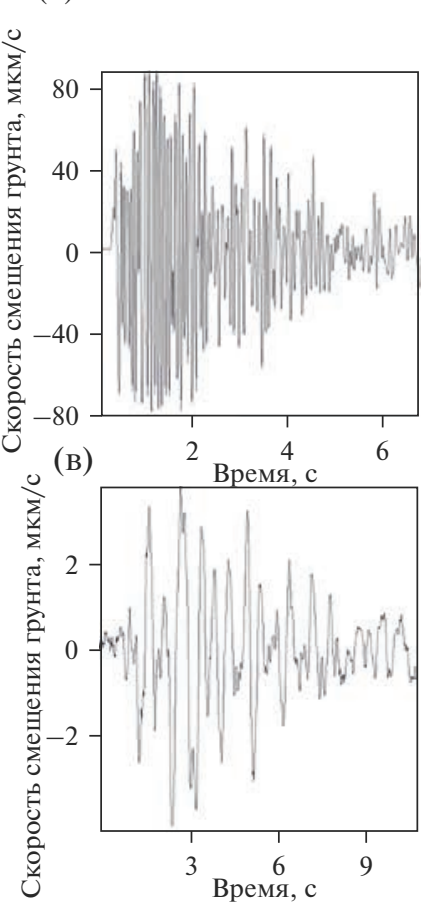

(б)

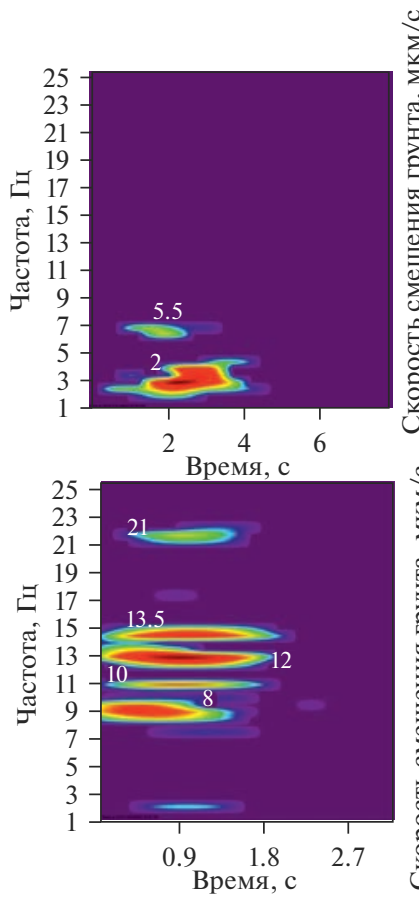

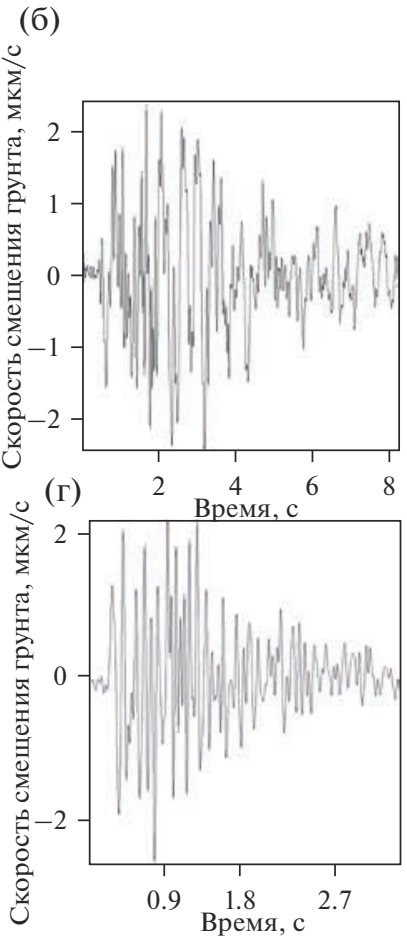

Рис. 3. Спектрограммы четырех типов В3, зарегистрированных на вертикальной составляющей (SHZ) PTCC SMA во время активизации вулкана Авачинский в октябре-декабре 2019 г. а - ВТЗ землетрясение 9.12.2019 г. в 14:54 с Ks =6.6, $\mathrm{H}=-1.42$ км; б - ГЗ 10.12.2012 г. в 23:03 с $K \mathrm{~s}=3.5, \mathrm{H}=1.8 \mathrm{км}$; в - Д3 18.11.2019 г. в 09:09 с $K \mathrm{~s}=2.7, \mathrm{H}=1.8 \mathrm{км;} \mathrm{г} \mathrm{-}$ “особое" землетрясение 5.11.2019 г. в 11:46 с Ks $=3.6, \mathrm{H}=1.8$ км.

считать, что механизм ДЗ связан с разрушением геосреды с низкой плотностью или заполнением трещины магмой/флюидом. ДЗ часто наблюдаются перед извержениями, когда в канале вулкана или трещинах повышается давление за счет поступления свежей порции магмы.

Особые землетрясения (O3). В потоке сейсмических событий, сопровождающих активизацию, были зарегистрированы 9 землетрясений с $K_{\mathrm{s}}=$ = 1.9-4.2, волновые формы которых отличались от волновых форм по общепринятой классификации В3. В начальной части записи таких землетрясений преобладала более низкая частота по сравнению с кода-волн (см. рис. 2г). Авторы назвали их “особые” землетрясения, которые на PTCC SMA имели сравнительно короткую запись с резким вступлением Р-волны и $t_{\mathrm{s}-\mathrm{p}}=0.5 \mathrm{c}$. По волновым формам и частотному спектру они напоминали основную фазу (main phase) особых (special-type) землетрясений, зарегистрированных во время слабой активизации вулкана Иво-Дзима, Япония [Uchida, Sakai, 2002]. На спектрограмме О3 выделяются пять линейных пятен спектральной плотности с частотами $f_{1}=8$ Гц, $f_{2}=$ $=10$ Гц, $f_{3}=12$ Гц, $f_{4}=14$ Гц, $f_{5}=21$ Гц (см. рис. 3г). Причем частота $f_{5}=21$ Гц появляется после вступления $\mathrm{S}$-волны.

ВУЛКАНОЛОГИЯ И СЕЙСМОЛОГИЯ № 32021
В целом на спектрограммах достаточно убедительно видны различия спектральных составов для типов В3, зарегистрированных во время активизации вулкана Авачинский в конце 2019 г. (см. рис. 3).

Рассмотрим некоторые особенности ОЗ. Как правило, первое вступление Р-волны О3 имело положительную полярность (7 из 9). Не исключено, что такие землетрясения могут быть связаны с “взрывными” процессами, происходящими в конусе вулкана. В пользу этого предположения говорят траектории движения частиц первых вступлений в плоскостях EW-Z и NS-Z, которые близки к направлению на источник (рис. 4), что наблюдается в ближней зоне при взрывах на выброс или вблизи границы с резким изменением свойств среды [Ромашев, 1980].

Сейсмическая активизация закончилась слабым высокочастотным спазматическим дрожанием, которое начало регистрироваться на РТСС SMA 25 декабря в 04:00 и прекратилось 26 декабря в 11:00 (рис. 5а, б). В амплитудном спектре хорошо выделяются три спектральных пика - "низкочастотный” с $f_{1}=5$ Гц и два четко выраженных “высокочастотных” с $f_{2}=19$ Гц и $f_{3}=23.5$ Гц (см. рис. 5в). Такая структура спектров близка к структуре спектров О3, где также выделяются близкие частоты. Кроме того, в этот период отмечалось

ВУЛКАНОЛОГИЯ И СЕЙСМОЛОГИЯ № 3202 
(a)

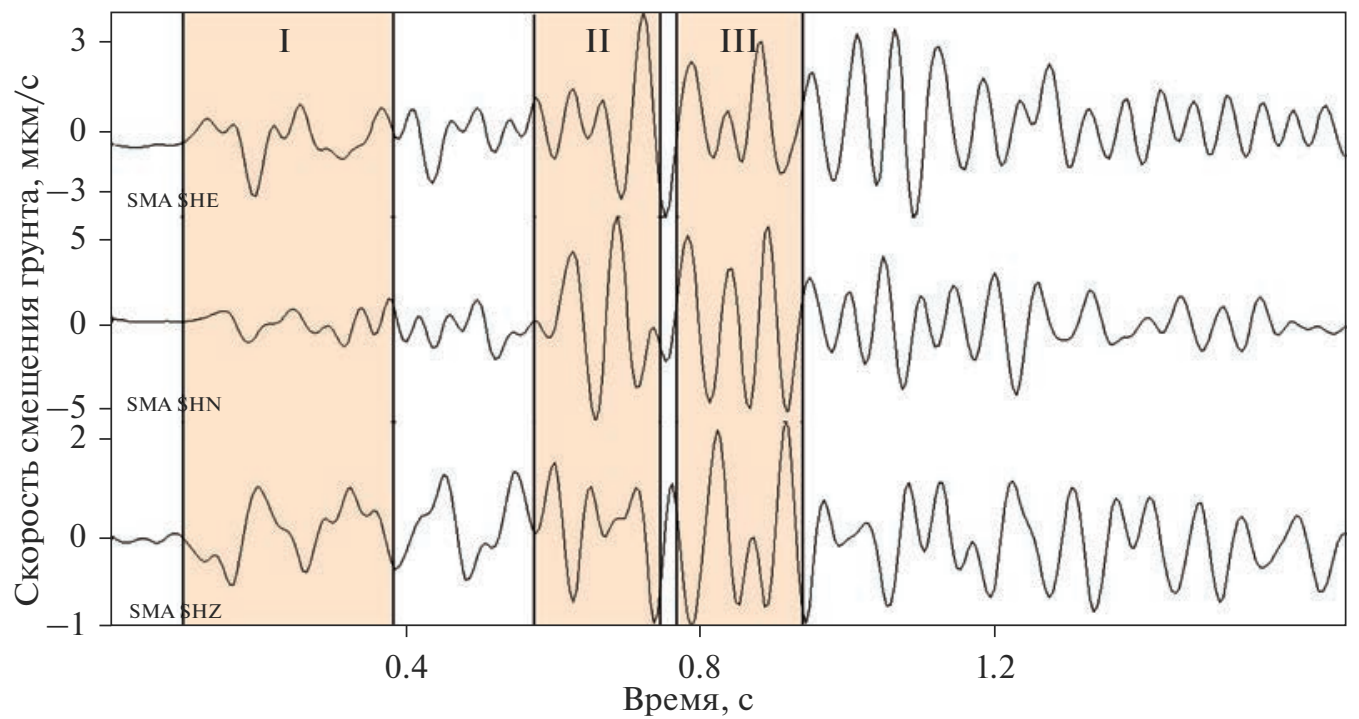

(б)
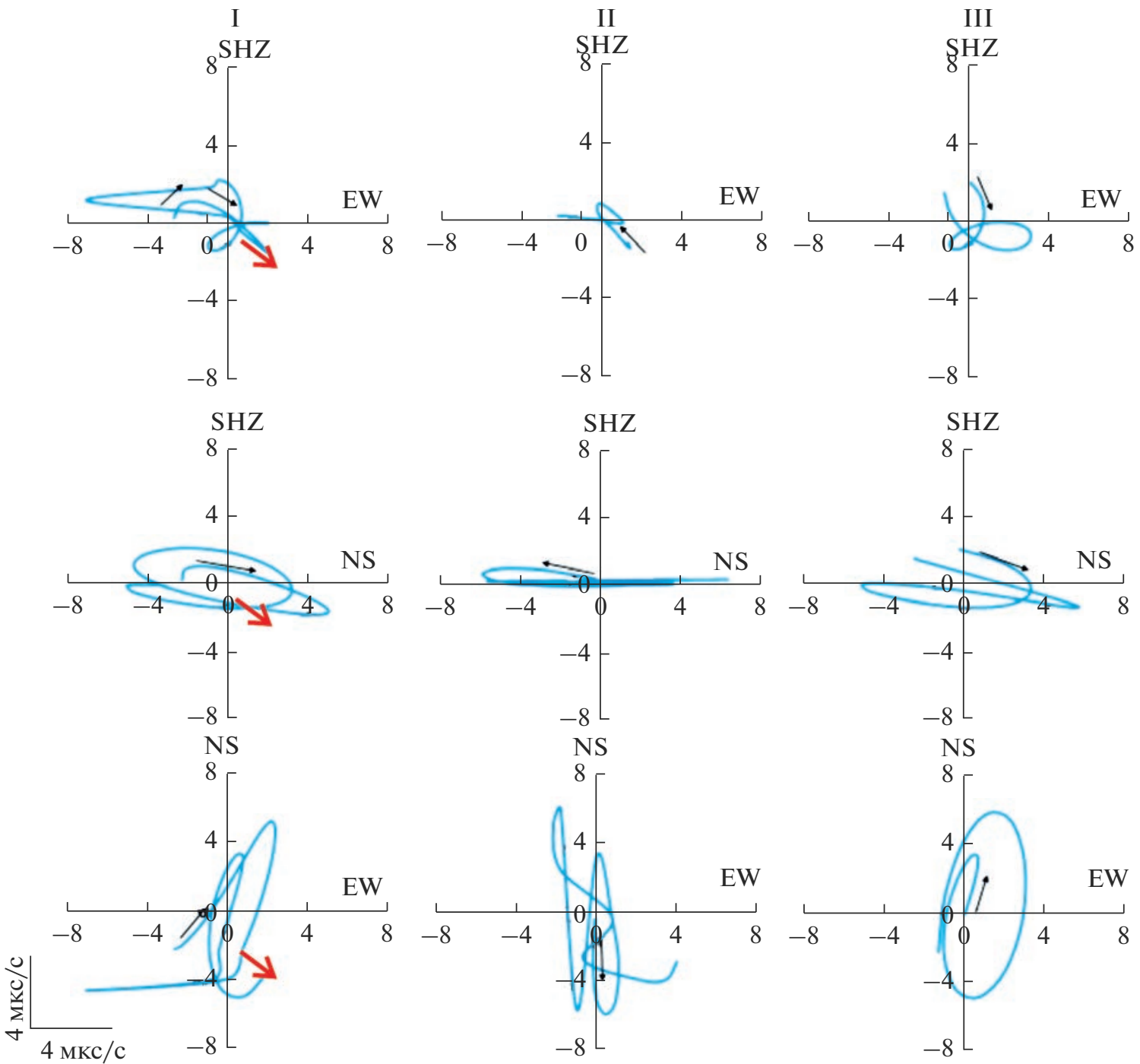

Рис. 4. Пример ОЗ, зарегистрированного 5 ноября 2019 г. на РТСС SMА (а); траектория движения грунта в различных группах волн (б). Красными стрелками показано направление на центр кратера, черными - направление движения грунта. Начало отсчета времени соответствует 11:46:35. 
(a)
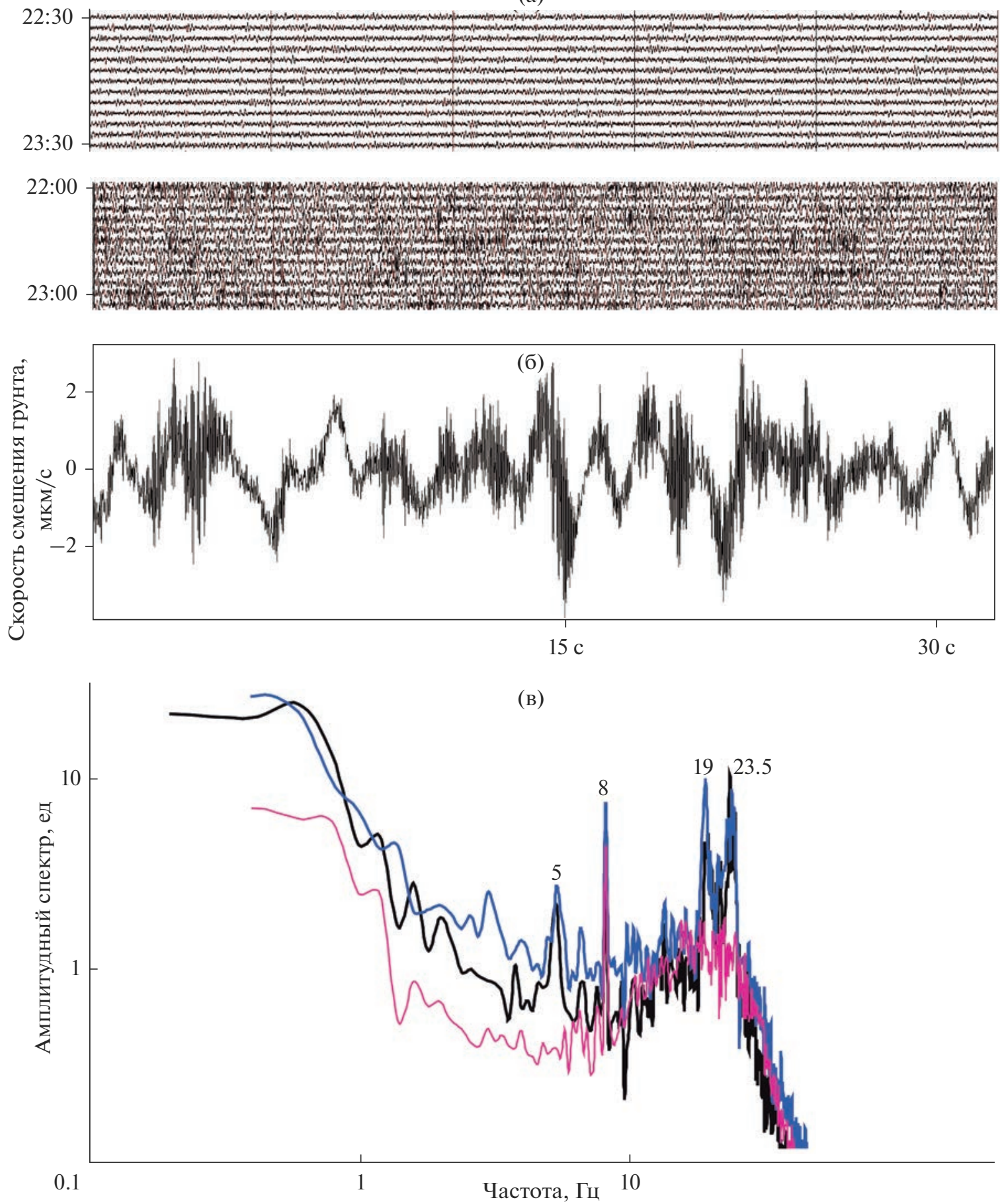

Рис. 5. Фрагменты часовых записей на вертикальной составляющей (SHZ) PTCC SMA 24 декабря 2019 г. при отсутствии ВД и 25 декабря с ВД (а); фрагмент записи ВД длительностью 30 с на вертикальной составляюшей (SHZ) PTCC SMA (б); амплитудные спектры для двух участков ВД и фона (в). Начало отсчета времени соответствует: а -5.12 .2019$ г., б-21:33:30.

усиление фумарольной активности. ВД могло возникнуть в результате интенсивного движения флюида по проницаемой зоне, сформированной в результате сейсмической активизации.

\section{НАБЛЮДАЕМОЕ СВЕЧЕНИЕ НА КРАТЕРЕ ВУЛКАНА}

Видеокамерой с РТСС AVH 27 октября 2019 г. в центральной части контура кратера ночью было 
(a)
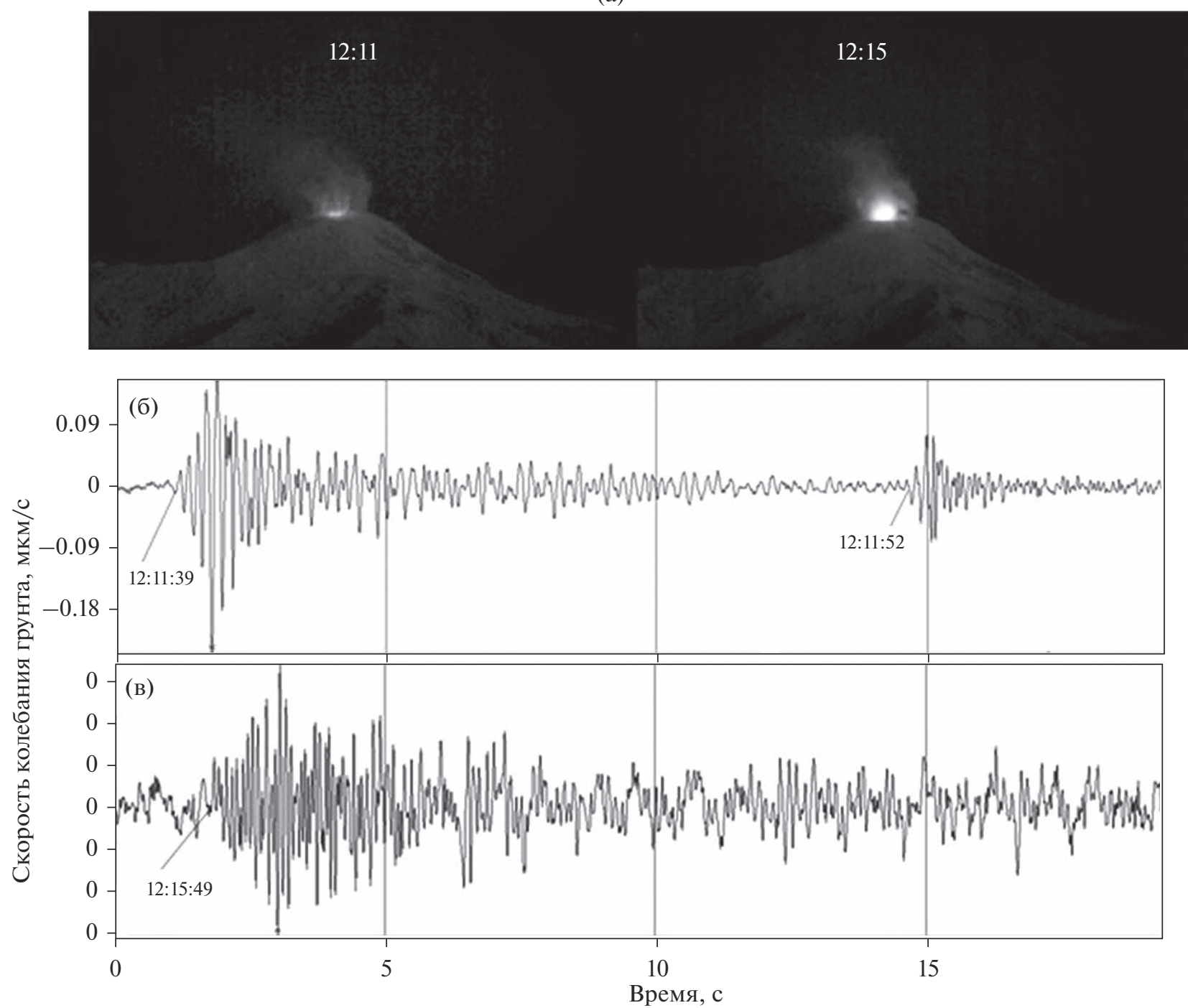

Рис. 6. Наиболее интенсивные вспышки, зафиксированные камерой РТСС AVН в 12:11 и 12:15 (а); фрагменты сейсмических записей на ВЧ канале РТСC SMA, соответствующие временным интервалам вспышек в 12:11 (б) и 12:15 (в) 8 декабря 2019 г. Начало отсчета времени соответствует: б - 12:11:37, в - 12:15:47.

зафиксировано слабое свечение в виде точки, которое периодически фиксировалось до конца декабря. Уникальное явление наблюдалось 8 декабря с 11:23 до 12:15, когда на месте свечения были зафиксированы 5 вспышек различной интенсивности (рис. 6). Сравнивая облики световых пятен, осредненных в минутном интервале, можно предположить, что их происхождение связано с взрывными процессами на различной глубине. Наиболее интенсивная вспышка произошла в 12:15 (см. рис. 6а). Облик светового пятна дает основание предположить, что она могла быть порождена взрывным процессом, возникшим в результате взаимодействия взрывоспособных вулканических газов с кислородом воздуха. Полусферическая форма и разлет продуктов взрыва указывают на то, что взрыв, по-видимому, произошел ниже поверхности кратера.

К сожалению, воздушная волна не зарегистрировалась акустическими станциями Камчатки связи с их большой удаленностью от вулкана. Однако во временной окрестности двух наиболее сильных вспышек в 12:11 и 12:15 на ВЧ канале PTCC SMA записались слабые сейсмические сигналы (рис. 7б, 7в). В первом случае зарегистрировано два сейсмических сигнала с интервалом между ними 7 с. Характер их волновых форм напоминает О3. Вторая вспышка сопровождалась сравнительно высокочастотным узкополосным сигналом, который очень напоминает колебания грунта при воздействии на него воздушной ударной волны. Длительность сейсмического сигнала 

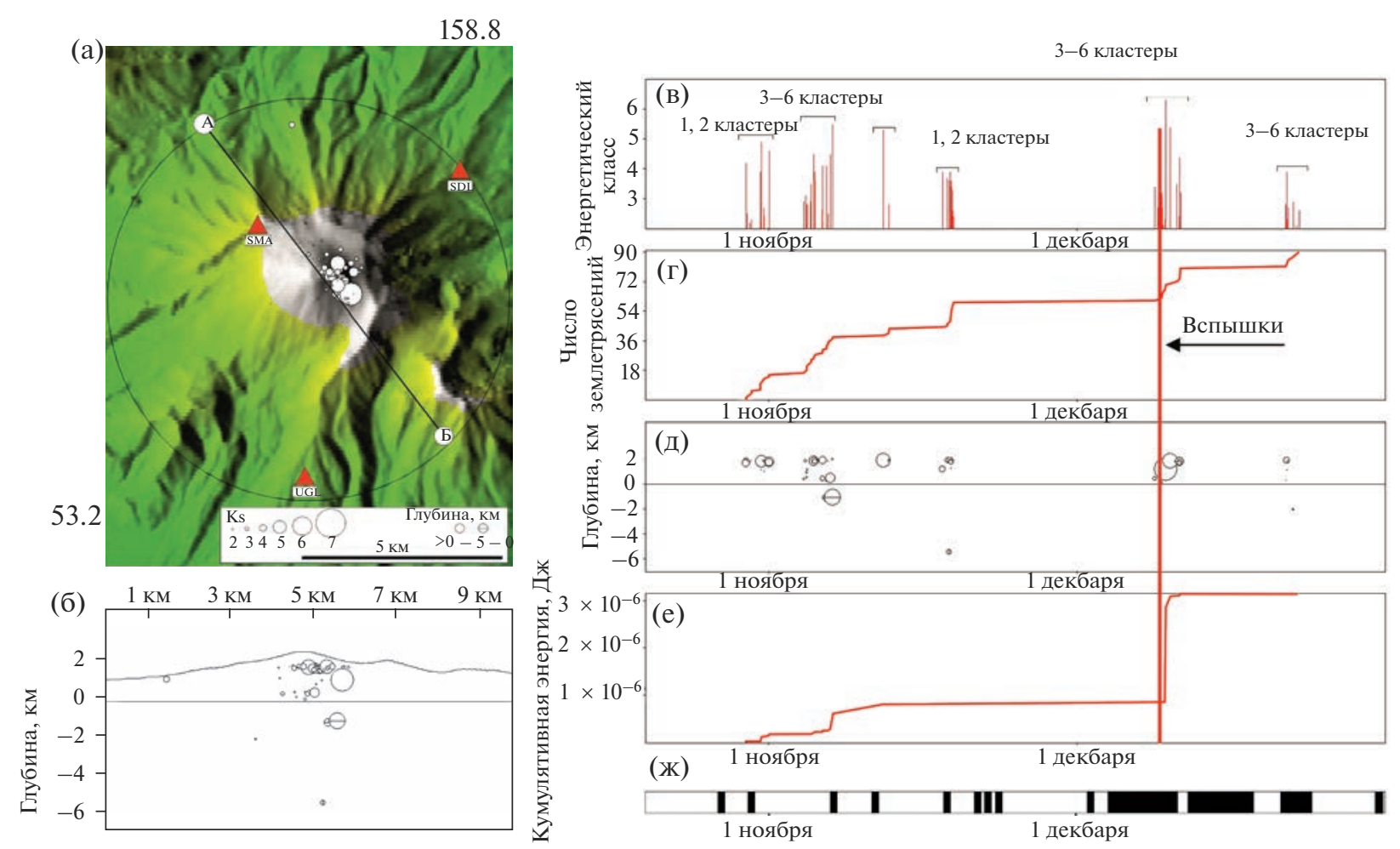

Рис. 7. Карта эпицентров землетрясений, произошедших в постройке вулкана Авачинский в октябре-декабре 2019 г. (a); проекция гипоцентров на вертикальную плоскость по линии А-Б (б); распределение во времени энергетического класса $(K)($ в); кумулятивная кривая числа землетрясений (г); глубины гипоцентров землетрясений (д); кумулятивная кривая энергии землетрясений (e); свечение в центральной части кратера (ж) (http://www.emsd.ru/ ssl/monitoring/main.htm). Вертикальной линией отмечен период наблюдаемых воздушных взрывов. Название PTCC: SMA - Coмма, SDL - Седловина, UGL - Угловая.

( 15 с) и длительное свечение вспышки могут указывать на многоактность этого процесса.

\section{ДИНАМИКА РАЗВИТИЯ СЕЙСМИЧНОСТИ АВАЧИНСКОГО ВУЛКАНА В КОНЦЕ 2019 Г.}

Сейсмичность вулкана в конце 2019 г. была представлена шестью роевыми последовательностями вулканических землетрясений, которые хорошо выделяются на кумулятивной кривой числа землетрясений (см. рис. 7г). Глубина основной массы очагов располагалась выше уровня моря $(0<\mathrm{h}<2 \mathrm{Kм})$ и тяготела к двум горизонтам $\sim 0.5$ и $\sim 1.8$ км н. У. м., а эпицентры были сосредоточены в северо-северо-восточном секторе конуса вулкана (см. рис. 7a, 7б). Энергетический класс В3 был заключен в пределах $1.4<K_{\mathrm{S}}<6.6$. Наибольшая энергия выделилась во время 5-го роя, когда произошло самое сильное землетрясения с $K_{\mathrm{S}}=6.6$ (см. рис. 7в).

В период сейсмической активности вулкана Авачинский с октября по декабрь 2019 г., согласно методике, описанной выше, было выделено 15 плоско-ориентированных кластеров, центры которых располагались в диапазоне глубин от 302 до
1842 м (табл. 1, рис. 8). Приведенные глубины с точностью до метра являются результатом программного выделения параметров кластера. Авторы осознают, что точность выделения координат недостаточная, чтобы говорить о метрах, но данные построения вполне оправданы для поиска общих закономерностей кластеризации землетрясений в роевых последовательностях.

В начале сейсмической активизации в роевых последовательностях выделялось по два кластера, на заключительной стадии по три кластера. Кластеры, в основном, располагались субвертикально с углом падения от $59^{\circ}$ до $84^{\circ}$, но кластеры № 1 , 8,12 имели субгоризонтальное расположение с центром на высоте 1800 м [Шакирова и др., 2020]. Рассматривалось процентное содержание типов В3 в кластерах (см. рис. 8а, врезка). Подавляюшее большинство землетрясений были представлены двумя типами ВТЗ и ДЗ. В начале активизации преобладали ВТЗ: кластеры № 5, 7 полностью были представлены ВТЗ, а в четырех последних - процент ВТЗ резко снизился. Обратная картина относится к ДЗ. Гибридные землетрясения были зарегистрированы только в 12-ом кла- 
Таблица 1. Параметры плоско-ориентированных кластеров вулканических землетрясений Авачинского вулкана в период с 28.10.2019 г. по 22.12.2019 г.

\begin{tabular}{c|c|c|c|c|c|c|c|c|c|c}
\hline № п/п & Дата & Угол падения & Азимут & $X, \mathrm{M}$ & $Y, \mathrm{M}$ & $Z, \mathrm{M}$ & $K_{\max }$ & $n$ & $S, \mathrm{Kм}^{2}$ & $\lambda, \%$ \\
\hline 1 & 29.10 .19 & 1.6 & 110.5 & 489188 & 5900238 & 1842 & 4.2 & 6 & 2.0 & 67 \\
2 & 31.10 .19 & 66.6 & 262.0 & 489265 & 5900604 & 1512 & 4.9 & 14 & 1.7 & 79 \\
3 & 04.11 .19 & 81.4 & 72.9 & 489515 & 5900534 & 1647 & 3.5 & 6 & 0.7 & 50 \\
4 & 04.11 .19 & 57.9 & 288.2 & 489328 & 5900775 & 1292 & 4.5 & 7 & 0.9 & 57 \\
5 & 06.11 .19 & 82.7 & 242.5 & 489291 & 5900574 & 1407 & 4.5 & 6 & 0.5 & 100 \\
6 & 06.11 .19 & 81.7 & 69.3 & 489262 & 5900434 & 811 & 5.5 & 7 & 2.9 & 86 \\
7 & 12.11 .19 & 73.6 & 257.9 & 489179 & 5900771 & 1635 & 5.3 & 6 & 1.2 & 100 \\
8 & 17.11 .19 & 10.9 & 20.0 & 489197 & 5901039 & 1814 & 3.9 & 14 & 2.9 & 50 \\
9 & 18.11 .19 & 83.9 & 104.9 & 488982 & 5900870 & 774 & 3.6 & 10 & 2.7 & 67 \\
10 & 08.12 .19 & 65.6 & 246.1 & 489146 & 5900960 & 997 & 3.2 & 8 & 2.1 & 50 \\
11 & 09.12 .19 & 81.6 & 251.8 & 489154 & 5900904 & 302 & 6.6 & 6 & 2.0 & 80 \\
12 & 10.12 .09 & 6.0 & 221.8 & 489353 & 5900585 & 1813 & 4.4 & 11 & 0.6 & 27 \\
13 & 21.12 .19 & 71.9 & 239.3 & 488828 & 5901139 & 1332 & 3.9 & 7 & 2.6 & 29 \\
14 & 22.12 .19 & 59.4 & 348.1 & 489092 & 5900708 & 503 & 2.9 & 6 & 5.2 & 17 \\
15 & 22.12 .19 & 59.9 & 203.5 & 489338 & 5900679 & 1039 & 3.1 & 6 & 3.8 & 0 \\
\hline
\end{tabular}

Примечание. $X, Y, Z$ - координаты центров кластеров (система координат UTM WGC-84); $K_{\mathrm{max}}-$ максимальный энергетический класс в кластере; $n, S$ - число землетрясений в кластере и его площадь; $\lambda$ - процентное содержание ВТЗ в кластере. Выделены субгоризонтальные кластеры.

стере, в то время как О3 регистрировались только в первой половине активизации (см. рис. 8а, врезка).

\section{ОБСУЖДЕНИЕ РЕЗУЛЬТАТОВ}

Результаты анализа сейсмических событий в октябре-декабре 2019 г. позволяют сделать определенные выводы о характере сейсмической активизации Авачинского вулкана и представить вероятную схему механизма ее развития.

Практически все землетрясения, сосредоточенные в постройке Молодого конуса, были достаточно слабыми $1.4<K_{\mathrm{S}}<6.6$. Центры выделенных кластеров находятся на высотах $200-1850$ м. В то же время, согласно геофизическим данным, периферический магматический очаг располагается на глубине от 0 до 2 км по данным [Мороз, Гонтовая, 2003], а по данным [Bushenkova et al., 2019] на глубинах ниже 2 км от дневной поверхности. Это указывает на отсутствие связи сейсмической активизации с процессами в вулканическом очаге.

Активизация пришлась на период конец октября-декабрь. Аналогичные сейсмические активизации происходили в периоды: февраль-апрель 1996 г., конец августа-октябрь 2001 г., октябрь-ноябрь 2005 г. [Сенюков и др., 2006]. Практически при всех активизациях землетрясения происходили в центральной части постройки конуса от уровня моря до кратера. С активизацией 2001 г. связана и слабая эксплозия с выбросом неболь- шого количества пепла и некрупных глыб при разрушении кратерной пробки с образованием в ней трещины. В ходе активизации 2005 г., также, как и в 2019 г., отмечалась слабая термоаномалия и несколько гибридных землетрясений [Сенюков и др., 2006].

В сейсмических активизациях ясно прослеживается определенная сезонность: все они приурочены к переходным периодам осень-зима или зима-весна. Это может указывать на связь сейсмических активизаций с резким повышением обводненности конуса вулкана за счет повышенного количества осадков осенью и таяния снежно-ледового покрова конуса весной. Молодой конус сложен, главным образом, толщей рыхлых вулканических отложений с отдельными прослоями лав в виде лавовых потоков и силлов, т.е. относительно свободно проницаем для метеорных вод. Летом, когда конус свободен от снега и льда, и зимой, когда он забронирован ледяным плащом и снегом, поступление атмосферной воды в виде дождя или талого снега существенно падает.

Наличие землетрясений четырех типов указывает на несколько механизмов их возникновения, причем роль этих механизмов изменялась в течение активизации. Она началась с формирования горизонтального кластера № 1 на высоте $\sim 1800$ м, который на две трети был представлен ВТЗ и на треть О3. На этом же уровне происходили события в горизонтальных кластерах № 8, 12. Причем доля ВТЗ в них снизилась до половины и менее 
(a)

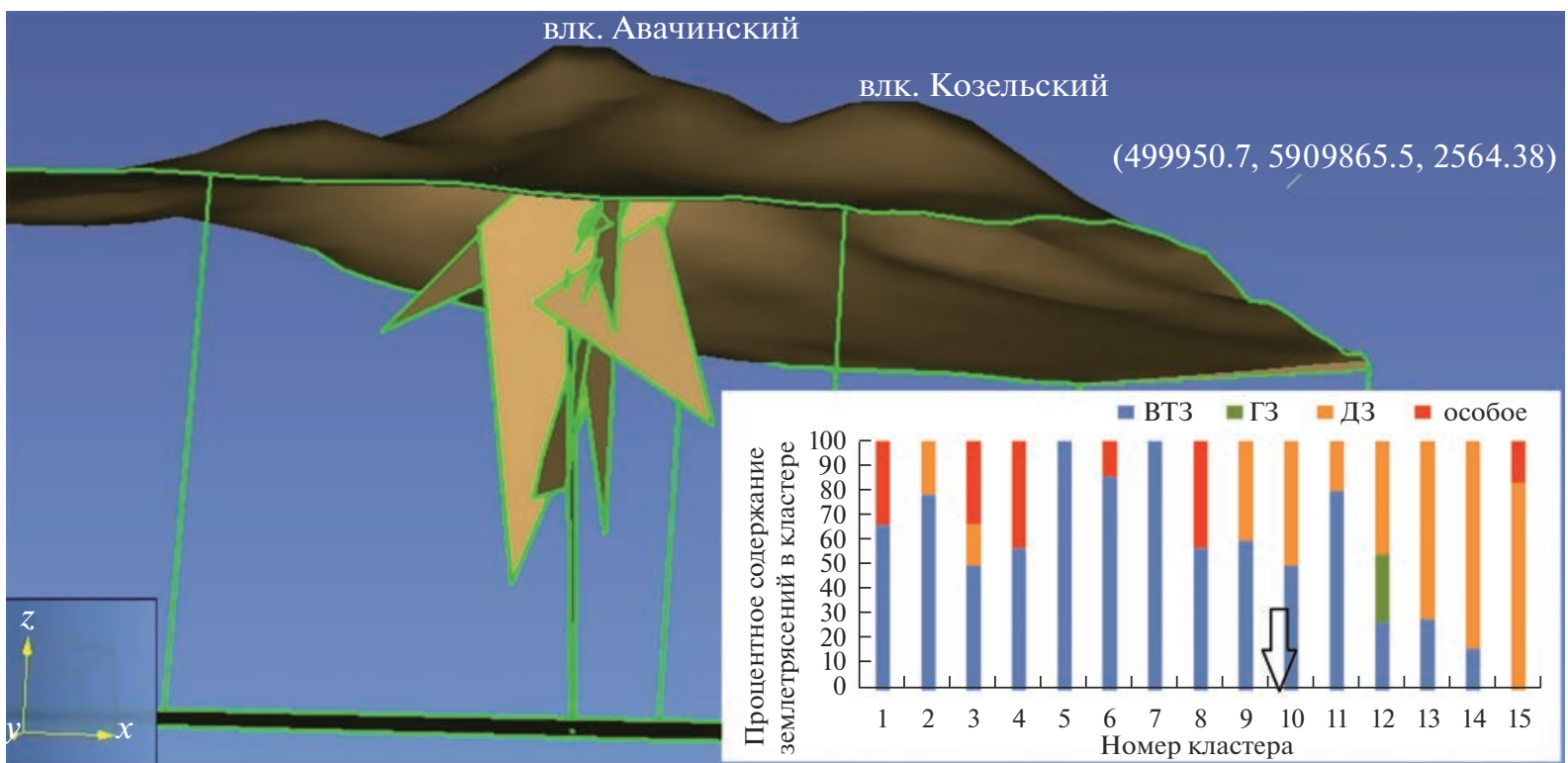

(б)

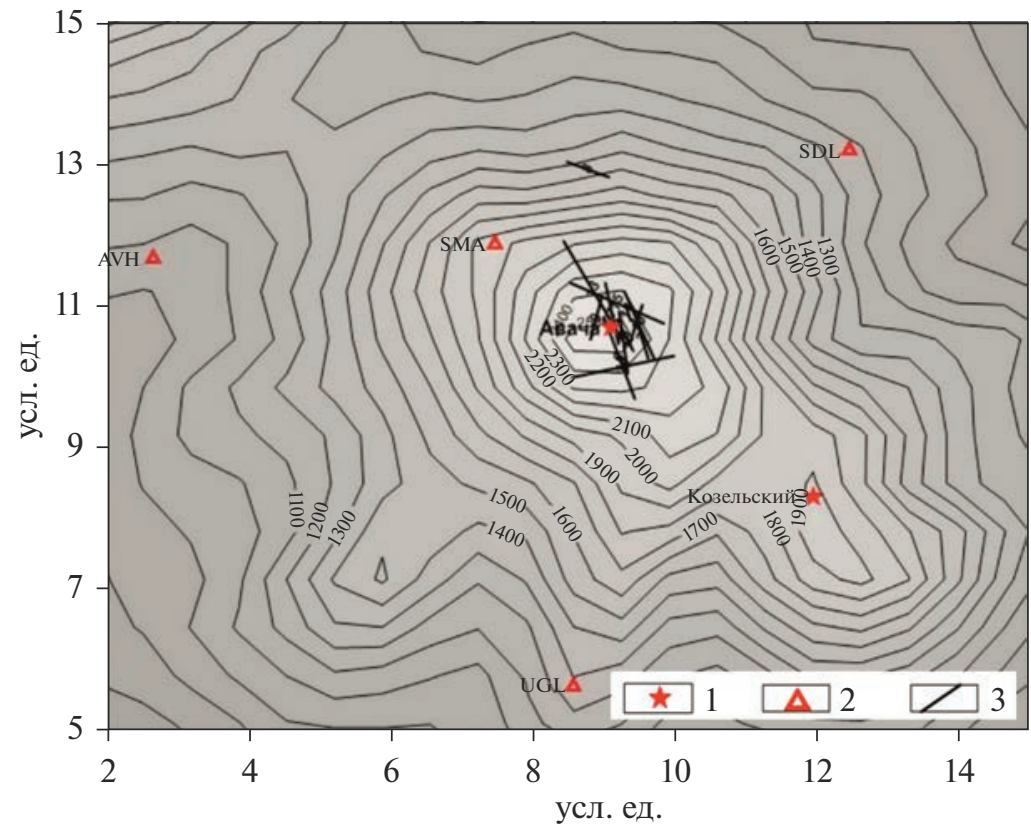

Рис. 8. 3D визуализация плоско-ориентированных кластеров В3, выделенных в период октябрь-декабрь 2019 г., с верхней плоскостью на высоте 1200 м (а). На врезке: график процентного содержания В3 в кластерах; стрелкой отмечены воздушные взрывы. Проекции площадок плоско-ориентированных кластеров землетрясений на горизонтальную плоскость на высоте 1500 м (б): 1 - вулканы; 2 - РТСС; 3 - проекции площадок кластеров.

трети соответственно. По-видимому, события этих кластеров фиксируют границу субгоризонтального горячего магматического тела и отражают его реакцию на контакт с холодными метеорными водами, что приводит к взрывному кипению с образованием трещин и возникновению В3. Можно предположить, что таким телом является силл, внедренный во время извержения 1991 г. с достаточной мощностью, чтобы сохранять не- которую пластичность. Последнее определило возникновение ДЗ в кластере № 12.

Субвертикальные кластеры № 5, 7 имеют близкие углы падения $\left(\sim 80-75^{\circ}\right)$, азимуты падения (ВСВ), события в которых были на $100 \%$ представлены ВТЗ, что может свидетельствовать о субвертикальном магматическом теле, также испытывающем контакт с метеорными водами. Таким телом могла быть дайка - канал поступле- 
ния магмы во время извержения 1991 г. Примечательно, что кластер № 6, состоящий почти из BT3, имеет азимут простирания, идентичный как в кластерах № 5, 7 (СС3-ЮЮВ), а также близкий угол падения, но противоположный азимут падения. Это является свидетельством того, что кластер № 6 отражает подобный процесс с противоположного борта частично закристаллизованного вулканического канала. Аналогичный азимут имеют 8 из 12 субвертикальных кластеров, а также трещина в кратере - результат извержения 1991 г.

Если в первую половину периода активизации преобладали ВТЗ и существенную долю составляли О3, то затем роль вулканотектонических событий постепенно снижалась, особые землетрясения практически исчезли, и стали преобладать ДЗ. Это может свидетельствовать о том, что процесс хрупкого разрушения уступил главную роль процессу, обусловленному взрывным вскипанием водного флюида в пределах лавово-пирокластической толщи конуса. Наличие длиннопериодных, особых и гибридных землетрясений говорит о различных механизмах генерации этих событий и их сочетаний с процессами хрупкого разрушения. Активизация закончилась высокочастотным спазматическим дрожанием, обусловленным интенсивным кипением метеорной воды с генерацией ВД 25 и 26 декабря.

Необычным явлением сейсмической активизации 2019 г. было свечение в кратере и вспышки над ним 8 декабря. Если слабое свечение в кратере можно объяснить просто прогревом кратерной трещины за счет усиления потока высокотемпературных фумарольных газов под воздействием растрескивания остывающих магматических тел в конусе, то яркие внезапные кратковременные вспышки, очевидно, имеют другую природу. Полусферическая форма самой сильной вспышки указывает на то, что, скорее всего, она возникла в результате взрыва непосредственно на поверхности лавовой пробки в кратере вулкана. Облик светового пятна дает основание предположить, что вспышка могла быть порождена взрывом, возникшим в результате возгорания восстановленных компонентов вулканических газов при их окислении кислородом воздуха. Такими компонентами, способными образовать взрывоспособную смесь с кислородом атмосферы, могут быть, прежде всего, $\mathrm{H}_{2}$ и СО. Так как вода и диоксид углерода являются основными компонентами магматических газов, а для глубинных флюидов характерен крайне низкий потенциал кислорода, то их доля может быть существенна.

Следует заметить, что воздушные взрывы на высоте 50-200 м над кратером фиксировались во время Большого трещинного извержения вулкана Толбачик в 1975 г. [Ковалев и др., 1979]. Во время этого извержения, по форме ударных воздуш- ных волн, также был выделен тип, который возникал в результате воздушных взрывов, возникающих за счет детонации взрывоспособных газов в атмосфере [Фирстов и др., 1978]. Наличие водорода в вулканических газах - известный факт, его горение на выходе фумарол наблюдалось на вулкане Горелый [Чаплыгин и др., 2015; Овсянников, Чирков, 2010].

Ориентировочная оценка фугитивности кислорода в магме извержения Авачи в 1991 г. была проделана по уравнению [Kress, Carmichael, 1991], используя валовый состав пород из [Иванов и др., 1995], и составы небольших глыб выброса 2001 г. (данные А.П. Максимова). В интервале $700^{\circ}-1000^{\circ} \mathrm{C}$, согласно такой грубой оценке, $\log \mathrm{O}_{\mathrm{O}_{2}}$ находится в пределах от соответствующего равновесию Ni-NO до превышающего его на единицу $\log f_{\mathrm{O}_{2}}$. Это типичные для островодужных андезитов значения. При таких условиях в равновесии с чистой $\mathrm{H}_{2} \mathrm{O}$ мольная доля водорода составит десятые доли процента. Такой же уровень концентраций будет иметь СО в равновесии с чистым $\mathrm{CO}_{2}$. В случае, если изначально окислительное состояние магмы соответствовало равновесию QFM (кварц-фаялит-магнетит), которое характерно для основных магм, то равновесные мольные доли $\mathrm{H}_{2}$ и СО составят первые проценты. Маловероятно, что при таких низких содержаниях эти газы могут образовать взрывоспособную смесь с кислородом воздуха.

Известно, что $\mathrm{H}_{2}$ при высоких температурах отличается от других летучих компонентов высокой проникающей способностью. При наличии градиента его концентраций он интенсивно мигрирует в область низкой концентрации. Это его свойство, в частности, используется в петрологических экспериментах при высоких давлениях: задавая извне давление водорода, регулируют его химический потенциал внутри запаянных металлических ампул. Так же ведет себя водород и в расплавах, тем самым влияя на окислительное состояние магм [Gaillard et al., 2003].

Можно предположить следуюшую схему для объяснения вспышек. В атмосфере давление (следовательно, и химический потенциал) $\mathrm{H}_{2}$ практически равен нулю. В то же время магмы всегда содержат некоторое количество воды, что, при низкой фугитивности кислорода, означает наличие заметных количеств $\mathrm{H}_{2}$. При этом парциальное давление $\mathrm{H}_{2}$ будет пропорционально общему давлению и его активности в расплаве и/или газовой фазе. В канале вулкана за счет разности потенциала $\mathrm{H}_{2}$ в атмосфере и в магме возможна его диффузия из остаточного расплава к поверхности. При сохраняющихся достаточно высоких температурах в канале вулкана такой процесс возможен и в стекле породы сформированной из магмы 
1991 г. По-видимому, на верхних уровнях канала в его более холодных участках могут быть закрытые трещины (небольшие полости), играющие роль “ловушек” слабого потока $\mathrm{H}_{2}$. Возникновение нескольких внезапных кратковременных вспышек можно объяснить вскрытием “ловушек”, вследствие происходящей сейсмической активизации, и взрывной реакцией водорода при смешивании с кислородом воздуха.

\section{ЗАКЛЮЧЕНИЕ}

Развитая на Авачинском вулкане сеть РТСС КФ ФИЦ ЕГС РАН позволила провести детальный анализ слабой сейсмичности, наблюдавшейся с октября по декабрь 2019 г. На основании волновых форм и спектрального состава В3 были выделены три общепринятых типа: вулканотектонические, гибридные и длиннопериодные. Кроме того был выделен четвертый - “особый” тип В3, отличающийся особенностями волновых форм. В начальной части записи О3 преобладала более низкая частота по сравнению с кодаволн. Характеристики этих землетрясений косвенно указывают, что они могут быть связаны с “взрывными” процессами, происходящими в конусе вулкана.

В сейсмической активизации Молодого конуса Авачинского вулкана в 2019 г. выделены 15 плоско-ориентированных кластеров и определены характеристики сейсмогенных площадок. Анализ их параметров позволяет предположить связь сейсмической активизации с взаимодействием горячих магматических тел извержения 1991 г. с метеорными водами. Наиболее вероятной причиной световых вспышек над кратером, наблюдавшихся 8 декабря, представляется взаимодействие обогащенного водородом вулканического газа при контакте с кислородом воздуха.

Таким образом, сейсмическая активизация вулкана в конце 2019 г. не была вызвана магматической активностью в вулканическом очаге. В дальнейшем возможны эпизодические повторения сейсмической активизации за счет взаимодействия остывающего в вулканическом канале магматического тела с метеорными водами. Однако, при появлении сейсмической активизации на глубинах, отвечающих положению вулканического очага (более 2 км от поверхности), с большой вероятностью следует ожидать возможного проявления вулканической активности.

Следует отметить, что Авачинский вулкан расположен в 27 км от краевого центра Камчатского края и представляет потенциальную угрозу для городов Петропавловск-Камчатский и Елизово и международного аэропорта Елизово. В связи с этим, изучение Авачинского вулкана в Институте вулканологии и сейсмологии ДВО РАН и КФ
ФИЦ ЕГС РАН планомерно проводилось в течение многих лет, однако, для краткосрочного прогноза извержения вулкана с высокой эффективностью необходимо усилить мониторинг геофизических параметров вблизи его постройки. В частности, для контроля процессов, происходящих в верхней части конуса, можно использовать мюонную томографию, по аналогии с тем, как она делается на вулканах Японии и Италии [Buontempo et al., 2010; László Oláh et al., 2018].

\section{БЛАГОДАРНОСТИ}

Авторы выражают благодарность А.В. Кирюхину за предоставление программы Frac-Digger для расчетов и А.Б. Белоусову за конструктивную критику и советы, способствующие лучшему изложению материала.

\section{ИСТОЧНИКИ ФИНАНСИРОВАНИЯ}

Работа выполнена в рамках государственного задания по проектам АААА-А19-119031590060-3, ААААA17-117050210046-7 и при поддержке РФФИ (проекТ № 18-05-00052).

\section{СПИСОК ЛИТЕРАТУРЫ}

Гордеев Е.И., Сенюков С.Л. Сейсмическая активизация вулкана Корякский в 1994 г.: гибридные сейсмические события и их применение для оценки вулканической опасности // Вулканология и сейсмология. 1998. № 4/5. С. 112-126.

Горшков Г.С. Сейсмические наблюдения в 1949 г. // Бюлл. вулканол. станций. 1954а. № 21. С. 19-39.

Горшков Г.С. Вулканическое дрожание, связанное с прорывом кратера Былинкиной // Бюлл. вулканол. станций. 1954б. № 23. С. 24-33.

Гущенко И.И. Извержения вулканов мира (каталог). М.: Наука, 1979. 476 с.

Дрознин Д.В., Дрознина С.Я. Интерактивная программа обработки сейсмических сигналов DIMAS // Сейсмические приборы. 2010. Т. 46. № 3. С. 22-34.

Дубровская И.К., Черкашин Р.И., Чирков С.А. Тепловой (ThermaCam SC 640) и сейсмический режим вулкана Авачинский в 2000-2018 гг. // Материалы конференции, посвященной Дню вулканолога "Современный вулканизм и связанные с ним процессы”, 28-29 марта 2019 г. Петропавловск-Камчатский: ИВиС ДВО РАН, 2019. C. 19-21.

Иванов Б.В., Флеров Г.Б., Масуренков Ю.П. и др. Динамика и состав продуктов извержения Авачинского вулкана в 1991 г. // Вулканология и сейсмология. 1995. № 4/5. C. 5-27.

Кирюхин А.В., Федотов С.А., Кирюхин П.А. Геохимическая интерпретация локальной сейсмичности, связанной с извержениями и активизацией вулканов Толбачик, Корякский и Авачинский, Камчатка, в 2008-2012 гг. // Вулканология и сейсмология. 2016. № 5. С. 3-20.

Кирюхин А.В., Федотов С.А., Кирюхин П.А. и др. Магматические питающие системы Корякско-Авачинской группы вулканов по данным локальной сейсмичности 
и режима прилегающих термальных источников // Вулканология и сейсмология. 2017. № 5. С. 3-17.

Ковалев Г.Н., Самойленко Б.И., Слезин Ю.Б. Воздушные вулканические взрывы // Докл. АН СССР. 1979. T. 248. № 1. С. 310-314.

Малик Н.А., Зеленский М.Е., Округин В.М. Температура и состав газа фумарол вулкана Авачинский (Камчатка) в 2013-2016 гг. // Вестник КРАУНЦ. Науки о Земле. 2017. № 1. Вып. 33. С. 21-33.

Малик Н.А., Некрасова М.Ю. Комплексные исследования активности Авачинского вулкана в 2013-начале 2020 гг.: наземные, видео- и сейсмические наблюдения // Вестник КРАУНЦ. Науки о Земле. 2020. № 2. Вып. 46. С. 41-56.

Мелекесцев И.В., Брайцева О.А., Двигало В.Н. и др. Исторические извержения Авачинского вулкана на Камчатке (попытка современной интерпретации и классификации для долгосрочного прогноза типов и параметров будущего извержения). Часть II. (1926-1991 гг.) // Вулканология и сейсмология. 1994. № 2. С. 3-23.

Мелекесцев И.В., Селиверстов Н.И., Сенюков С.Л. Информационное сообщение об активизации в октябре 2001 г. вулкана Авачинский на Камчатке и проведенных исследованиях // Вулканология и сейсмология. 2002. № 2. С. 79-80.

Мороз Ю.Ф., Гонтовая Л.И. Глубинное строение района Авачинско-Корякской группы вулканов на Камчатке // Вулканология и сейсмология. 2003. № 4. С. 3-10.

Муравьев Я.Д. К вопросу о прогнозе извержений вулкана Авачинский (Камчатка) // Материалы конференции, посвященной Дню вулканолога "Современный вулканизм и связанные с ним процессы”, 29-30 марта 2020 г. Петропавловск-Камчатский: ИВиС ДВО РАН, 2020. C. $50-58$.

Нуждина И.Н., Кожевникова Т.Ю., Толокнова С.Л. и др. Авачинская группа вулканов // Землетрясения России в 2017 г. Обнинск: ФИЦ ЕГС РАН, 2019. С. 177.

Овсянников А.А., Чирков С.А. Состояние вулкана Горелый в июне 2010 г. // Вестник КРАУНЦ. Науки о Земле. 2010. № 1. Вып. 15. С. 10.

Ромашев А.Н. Особенности действия крупных подземных взрывов. М.: Недра, 1980. 213 с.

Сенюков С.Л., Нуждина И.Н., Дрознина С.Я. и др. Сейсмичность Авачинского вулкана в 1994-2005 гг. // Материалы научно-технической конференции "Геофизический мониторинг Камчатки”, ПетропавловскКамчатский, 17-18 января 2006 г. ПетропавловскКамчатский: ГС РАН, 2006. С. 101-105.

Сенюков С.Л. Мониторинг активности вулканов Камчатки дистанционными средствами наблюдений в 2000-2004 гг. // Вулканология и сейсмология. 2006. № 3. C. $68-78$.

Токарев П.И. Извержения и сейсмический режим вулканов Ключевской группы (1949-1963 гг.). М.: Наука, 1966. 104 c.

Фирстов П.П., Адушкин В.В., Сторчеус А.В. Ударные воздушные волны, зарегистрированные во время Большого трещинного извержения в сентябре 1975 г. // Докл. AH CCCP. 1978. T. 259. № 5. C. 1078-1081.

Чаплыгин И.В., Таран Ю.А., Дубинина Е.О. и др. Химический состав и металлоносность магматических газов вулкана Горелый (Камчатка) // Докл. АН. 2015. Т. 463. № 1. C. 85.

Шакирова А.А. Черных Е.В., Фирстов П.П., Кирюхин А.В. Слабая сейсмическая активизация вулкана Авачинский в октябре-декабре 2019 г. // Материалы конференции, посвященной Дню вулканолога "Современный вулканизм и связанные с ним процессы”, 29-30 марта 2020 г. Петропавловск-Камчатский: ИВиС ДВО PAH, 2020. C. 50-58.

Buontempo S., De Lellis G., D'Auria L. Perspectives for the radiography of Mt. Vesuvius by cosmic ray muons // Earth Planets Space. 2010. V. 62. P. 131-137.

https://doi.org/10.5047/eps.2009.05.005

Bushenkova N., Koulakov I., Senyukov S. et al. Tomographic Images of Magma Chambers Beneath the Avacha and Koryaksky Volcanoes in Kamchatka // J. Geographical Research: Solid Earth. 2019. Iss. 9. V. 124. P. 9694-9713.

https://doi.org/10.1029/2019JB017952

Cannata A., Diliberto I.S., Alparone S. et al. Multiparametric Approach in Investigating Volcano-Hydrothermal Systems: the Case Study of Vulcano (Aeolian Islands, Italy) // Pure Appl. Geophys. 2012. V. 169. P. 167-182.

https://doi.org/10.1007/s00024-011-0297-z

Droznin D.V., Droznina S.Ya. Interactive DIMAS program for processing seismic signals // Seismic Instruments. 2011. V. 47. № 3. P. 215-224.

https://doi.org/10.3103/S0747923911030054

Gomez D.M., Torres R.A., Seidl D. et al. Tornillo seismic events at Galeras volcano, Colombia: A summary and new information from broadband three-component measurements // Ann. Geofis. 1999. V. 42. P. 365-378.

Gaillard F., Schmidt B., Mackwell S., McCammon C. Rate of hydrogen-iron redox exchange in silicate melts and glasses // Geochim. Cosmochim. Acta. 2003. V. 67. № 13. P. 24272441.

Kiryukhin A., Lavrushin V., Kiryukhin P. et al. Geofluid Systems of Koryaksky-Avachinsky Volcanoes (Kamchatka, Russia) // Geofluids. 2017. Article ID 4279652. P. 1-21. https://doi.org/10.1155/2017/4279652

Kress V.C., Carmichael S.E. The compressibility of silicate liquids containing $\mathrm{Fe}_{2} \mathrm{O}_{3}$ and the effect of composition, temperature, oxygen fugacity and pressure on their redox states // Contributions to Mineralogy and Petrology. 1991. V. 108. P. 82-92.

László Oláh, Hiroyuki K.M. Tanaka, Takao Ohminato, Dezső Varga. High-definition and low-noise muography of the Sakurajima volcano with gaseous tracking detectors // Scientific reports. 2018. 8:3207. P. 1-13.

https://doi.org/10.1038/s41598-018-21423-9

Minakami T. Fundamental research for predicting volcanic eruption. Part 1 // Bull. Earthq. Res. Inst. 1961. V. 38. P. 497-544.

McNutt S.R. Seismic monitoring and eruption forecasting of volcanoes: A review of the state-of-the-art and case histories. Monitoring and Mitigation of Volcano Hazards / Eds R. Scarpa, R. Tilling. Berlin, N.Y.: Springer-Verlag, 1996. P. 99-146. https://doi.org/10.1007/978-3-642-80087-0

Milluzzo V., Cannata A., Alparone S. et al. Tornillos at Vulcano: Clues to the dynamics of the hydrothermal system // J. Volcanol. and Geotherm. Res. 2010. V. 198 P. 377-393. https://doi.org/10.1016/j.jvolgeores.2010.09.022 
Power J.A., Lahr J.C., Page R.A. et al. Seismic evolution of the 1989-1990 eruption sequence of Redoubt Volcano, Alaska // J. Volcanol. and Geotherm. Res. 1994. Iss. 1-4. V. 62. P. 69-94.

https://doi.org/10.1016/0377-0273(94)90029-9
Uchida N., Sakai T. Analysis of peculiar volcanic earthquakes at Satsuma-Iojima volcano // Earth Planets Space. 2002. V. 54. P. 197-209.

Zobin V.M. Introduction to volcanic seismology / Third edition. Amsterdam: Elsevier, 2017. 559 p.

\title{
Activation of Avachinsky volcano in 2019
}

\author{
P. P. Firstov ${ }^{1, *}$, A. A. Shakirova ${ }^{1, * *}$, A. P. Maksimov ${ }^{2}$, and E. V. Chernykh ${ }^{2}$ \\ ${ }^{1}$ Kamchatka Branch of the Federal Research Center "Unified Geophysical Service of the Russian Academy of Sciences", \\ bulvar Piipa, 9, Petropavlovsk-Kamchatsky, 683006 Russia \\ ${ }^{2}$ Institute of Volcanology and Seismology, Far East Branch, Russian Academy of Sciences, \\ bulvar Piipa, 9, Petropavlovsk-Kamchatsky, 683006 Russia \\ *e-mail:firstov@emsd.ru \\ **e-mail: shaki@emsd.ru
}

Based on the study of the waveforms and spectral composition of earthquakes recorded during the activation of Avachinsky volcano in 2019, three generally accepted types of volcanic earthquakes (VE) were identified: volcano-tectonic, hybrid and long-period, as well as the fourth - a "special" type of VE, characterized by differ of waveforms. 15 plane-oriented clusters have been identified and the characteristics of seismogenic areas have been determined. Analysis of the seismic events recorded in autumn 2019 in the Young Cone of Avachinsky Volcano suggested a connection between the activation of the 1991 eruption in the body of the cone and their interaction with atmospheric precipitation with magmatic bodies. The most likely cause of the light flashes over the crater on December 8 is the interaction of a hydrogen-rich volcanic gas in contact with atmospheric oxygen.

Keywords: activation, seismicity, plane-oriented clusters, hydrothermal activity 